\title{
Nature of C-(A)-S-H Phases Formed in the Reaction Bentonite/Portlandite
}

\author{
Raúl Fernández, Lorena González, Ana Isabel Ruiz, and Jaime Cuevas \\ Department of Geology and Geochemistry, Faculty of Sciences, Autonomous University of Madrid, \\ Campus Cantoblanco, 28049 Madrid, Spain \\ Correspondence should be addressed to Raúl Fernández; raul.fernandez@uam.es
}

Received 30 September 2014; Accepted 3 December 2014; Published 18 December 2014

Academic Editor: Miguel A. Huerta-Diaz

Copyright @ 2014 Raúl Fernández et al. This is an open access article distributed under the Creative Commons Attribution License, which permits unrestricted use, distribution, and reproduction in any medium, provided the original work is properly cited.

\begin{abstract}
Reactions between bentonite/montmorillonite and portlandite have been studied in the context of the engineered barriers of a purpose built repository for the deep geological disposal of spent fuel and high-level radioactive wastes. Portlandite was selected as the representative material of cement leaching in the early alkaline stage expected in a repository when conventional Ordinary Portland Cement (OPC) is used. Eight different batch experiments were performed for a reaction time near to two months, including bentonite or montmorillonite at montmorillonite/portlandite molar ratios of $2: 1$ and $3: 1$ under hydrothermal conditions. Temperatures of reactions were maintained constant at either 60 or $120^{\circ} \mathrm{C}$. Calcium silicates hydrates with limited substitution of $\mathrm{Al}$ for $\mathrm{Si}(\mathrm{C}-(\mathrm{A})-\mathrm{S}-\mathrm{H}$ phases with $\mathrm{Al} / \mathrm{Si}<0.3)$ were formed with different structures and compositions as a function of the reaction conditions. Orthorhombic $11 \AA \AA$-tobermorite-type phase was detected in experiments at $120^{\circ} \mathrm{C}$ while a more disordered monoclinic tobermorite formed at $60^{\circ} \mathrm{C}$. These results are useful for the interpretation of experimental data in more complex experiments using concrete or cement pastes and bentonite, where $\mathrm{C}-(\mathrm{A})-\mathrm{S}-\mathrm{H}$ phases of variable compositions can precipitate, in addition to the characteristic cement hydrates and other secondary minerals carbonates.
\end{abstract}

\section{Introduction}

Concrete and compacted bentonite are considered by many international organizations as engineered barriers for the disposal of spent fuel and high-level radioactive waste in deep geological repositories. Reactions between the concrete and bentonite will likely produce an impact on the mineralogical and physicochemical properties at the interface of both materials that could compromise their safety functions in the long term.

Concrete is made of cement, aggregates (inert granular materials such as sand, gravel, or crushed stone), and water. Additionally, supplementary cementing materials (e.g., fly ash, silica fume) and chemical admixtures can be incorporated. For laboratory experiments, usually cement mortar is used instead of concrete. The cement/bentonite interactions, and more generically, cement/clay interactions, have been studied by laboratory experiments, either at low water/solid ratios in advective transport cells, using compacted bentonite and cement mortar probes $[1,2]$, or at high water/solid ratios, studying mineral reactions in batch reactors $[3,4]$. In addition, geochemical models have been used to explain the results or pursuing the extrapolation of mineral reactivity in the long term [5-7].

OPC contains highly alkaline materials such as portlandite $\mathrm{Ca}(\mathrm{OH})_{2}$, sodium, and potassium hydroxides. The pore fluid of cement/concrete has, therefore, high alkalinities with $\mathrm{pH}>12$. When emplacing a cementitious repository in an argillaceous rock formation, the highly alkaline pore fluid from the repository will migrate by the introduction of groundwater (mainly by diffusion) and by the interaction with both the bentonite barrier and the clay formation. Such a highly alkaline pore fluid of cement/concrete is called alkaline plume.

Experimental evidence demonstrates that the impact of the alkaline plume on bentonite will generate partial dissolution of montmorillonite, formation of illite/smectite mixed layers $[8,9]$, precipitation of $\mathrm{Na} / \mathrm{K}$-zeolites and trioctahedral Mg smectite $[4,10,11]$ under hyperalkaline conditions $(\mathrm{pH}>$ 12.5), and formation of calcium silicates hydrates (C-S-H) 
and Mg-clays $[3,12]$ under alkaline conditions $(\mathrm{pH}<12.5)$. The nature of the products largely depends on the experimental conditions, including temperature, $\mathrm{pH}$, clays and solution compositions, and duration of the reaction [13]. The importance of the identification of the reaction sequence is that the reaction products will help to determine the prediction of the reactivity of the system in the long term.

It has also been observed that accessory minerals in bentonite play a role in the reactivity and participate in the precipitation of $\mathrm{C}-\mathrm{S}-\mathrm{H}$, by means of different reactions on silicate mineral surfaces [14]. These C-S-H phases exhibit different morphologies (typically fibrous or laminar) and chemical compositions. They have been observed within a large range of molar $\mathrm{Ca} / \mathrm{Si}$ ratios that may extend from 0.8 to near 2 [15].

At the laboratory scale, C-S-H phases are difficult to identify because they usually precipitate accompanied by other secondary minerals at the $\mu \mathrm{m}-\mathrm{nm}$ pore scale. C-S$\mathrm{H}$ phases are typically amorphous or poorly crystalline and do not preserve well at ambient conditions insofar as they are easily carbonated. In addition, C-S-H phases contain water, which makes their characterization by conventional methods without first drying them difficult. In many cases, $\mathrm{C}-\mathrm{S}-\mathrm{H}$ phases are vaguely identified as being tobermoritelike when they exhibit low $\mathrm{Ca} / \mathrm{Si}$ ratios or jennite-like for high $\mathrm{Ca} / \mathrm{Si}$ ratios [16]. This structural aspect of the C-S-H phases has been included in a recent thermodynamic solidsolution model [17]. The identification of C-S-H phases is further complicated by the possible partial substitution of $\mathrm{Al}$ for $\mathrm{Si}$ to form calcium aluminum silicates hydrates (C-A-S$\mathrm{H}$ ), as well as the possible $\mathrm{K}, \mathrm{Na}$, and $\mathrm{Mg}$ replacement for $\mathrm{Ca}$ in these phases $[18,19]$. Magnesium silicates hydrates (M-S$\mathrm{H})$ phases may form when high contents of $\mathrm{Mg}$ are available in the reaction water. The $\mathrm{M}-\mathrm{S}-\mathrm{H}$ phases exhibit $\mathrm{Mg} / \mathrm{Si}$ ratios between $4: 1$ and $1: 1$ and have different structures than C-S-H. Although both types of phases may coexist, C-S$\mathrm{H}$ contains little magnesium while $\mathrm{M}-\mathrm{S}-\mathrm{H}$ contains little calcium [20].

In addition to laboratory experiments, zeolites, C-S-H, and C-A-S-H phases have also been observed in natural and archaeological analogues $[21,22]$. Consequently, geochemical models of cement/bentonite interaction usually try to predict the long-term stability of a wide range of possible C-S$\mathrm{H}$ and C-A-S-H phases of varying composition, which in most cases are based on thermodynamic data derived from theoretical calculations [23]. Although the present study does not improve the estimates of thermodynamic properties of $\mathrm{C}-\mathrm{S}-\mathrm{H}$ and C-A-S-H phases, it addresses the uncertainty in the identification of such phases in the context of cement and bentonite barriers interaction.

The objective of the present study was to therefore force the precipitation of C-S-H phases under simplified and controlled conditions in order to identify their chemical composition and character to further implement the interpretation of reaction fronts in real or simulated cement/bentonite interfaces. The reaction system considers only bentonite and portlandite, but different reaction conditions have been applied: two temperatures $\left(60\right.$ and $\left.120^{\circ} \mathrm{C}\right)$, two montmorillonite/portlandite ratios $(2: 1$ and $3: 1)$, and two clays (natural bentonite and its $<2 \mu \mathrm{m}$ size fraction).

\section{Materials and Methods}

The bentonite used in this study is known as the FEBEX bentonite and was selected by ENRESA as the reference bentonite to be used for a deep geological repository in Spain. The FEBEX bentonite is extracted from the deposit at La Serrata of Nijar (Almería, Spain) [24]. This bentonite is characterized by a high content in montmorillonite $(92 \pm$ 3 wt.\%) and variable amounts in quartz, potassium feldspars, plagioclases, cristobalite, and calcite, all below $2 \mathrm{wt} . \%$. The distribution of exchangeable cations is dominated by $\mathrm{Ca}, \mathrm{Na}$, and $\mathrm{Mg}$ in similar proportions [25]. Two types of samples were used: (a) a natural FEBEX bentonite grinded to a grain size $<1 \mathrm{~mm}$ and (b) the size fraction $<2 \mu \mathrm{m}$ of this bentonite. The latter was obtained by ultrasonic dispersion in distilled water $(10 \mathrm{~g} / \mathrm{L})$ and sedimentation in a $1 \mathrm{~L}, 30 \mathrm{~cm}$ length cylindrical column. After $18 \mathrm{~h}$ at $20^{\circ} \mathrm{C}$, the upper $17.5 \mathrm{~cm}$ of the water column was extracted. The suspension was flocculated by adding $20 \mathrm{~cm}^{3} 0.25 \mathrm{M} \mathrm{CaCl}_{2}$, acidified to $\mathrm{pH} 4.5$ using $1 \mathrm{M} \mathrm{HCl}$, in order to saturate the montmorillonite exchange complex with $\mathrm{Ca}^{2+}$ and to prevent the presence of carbonates. The suspension was centrifuged and consecutively soaked and centrifuged with $25 \mathrm{~cm}^{3}$ of distilled water first and then two times with the same volume of absolute ethanol, in order to eliminate the calcium salt excess. The resulting slurry was dried at $60^{\circ} \mathrm{C}$.

Purification of $\mathrm{Ca}(\mathrm{OH})_{2}$ was prepared by calcination of a commercial $\mathrm{Ca}(\mathrm{OH})_{2}$ Merck p.a. grade chemical reagent at $900^{\circ} \mathrm{C}$ for $1 \mathrm{~h}$ with the objective of avoiding the formation of $\mathrm{CaCO}_{3}$ by reaction with atmospheric $\mathrm{CO}_{2}$. The $\mathrm{CaO}$ produced after calcination was cooled to room temperature within a globe box, free of atmospheric $\mathrm{CO}_{2}$, and rehydrated again to produce the desired $\mathrm{Ca}(\mathrm{OH})_{2}$ under controlled conditions. Distilled water was heated to boiling for 30 minutes before its use in order to liberate any dissolved $\mathrm{CO}_{2}$ from water.

A set of four presetting experiments of 1-week duration were performed at different montmorillonite/portlandite ratios in order to establish the optimum reaction ratios. For simplification, the assumed montmorillonite composition was $\mathrm{Ca}_{0.165} \mathrm{Mg}_{0.33} \mathrm{Al}_{1.67} \mathrm{Si}_{4} \mathrm{O}_{10}(\mathrm{OH})_{2}$, as assumed by Savage et al. $[15,26]$, but replacing Na by $\mathrm{Ca}$. Then, the stoichiometric molar ratio for the montmorillonite dissolution in presence of portlandite is

$$
\begin{gathered}
\mathrm{Ca}_{0.165} \mathrm{Mg}_{0.33} \mathrm{Al}_{1.67} \mathrm{Si}_{4} \mathrm{O}_{10}(\mathrm{OH})_{2}+2.34 \mathrm{Ca}(\mathrm{OH})_{2}+2 \mathrm{H}_{2} \mathrm{O} \\
=2.505 \mathrm{Ca}^{2+}+0.33 \mathrm{Mg}^{2+}+1.67 \mathrm{Al}(\mathrm{OH})_{4}{ }^{-}+4 \mathrm{HSiO}_{3}{ }^{-}
\end{gathered}
$$

$5 \mathrm{~g}$ of natural FEBEX bentonite (assumed $4.60 \mathrm{~g}$ of montmorillonite) was mixed with $\mathrm{Ca}(\mathrm{OH})_{2}$ in $1: 1,2: 1,3: 1$, and $4: 1$ montmorillonite/ $\mathrm{Ca}(\mathrm{OH})_{2}$ molar ratios. The 4 presetting experiments were performed at a solid/liquid mass ratio $1: 3$. 


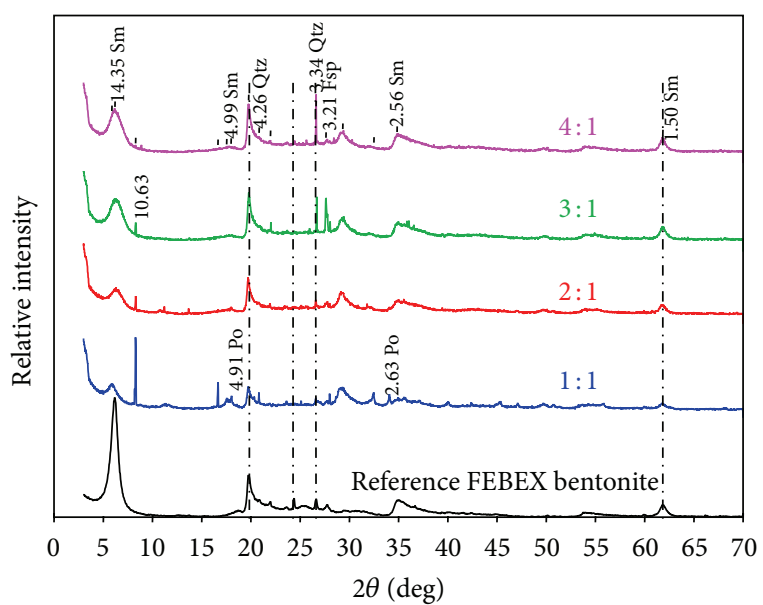

FIGURE 1: XRD of reacted samples after 1 week at montmorillonite/portlandite molar ratios 1:1 (blue), 2:1 (red), $3: 1$ (green), and $4: 1$ (pink) compared to the unreacted reference FEBEX bentonite. Note that XRD reflections are labeled with $d$ spacings $(\AA)$. Sm: smectite; Qtz: quartz; Fsp: feldspar; and Po: portlandite.

The experiments were maintained at constant temperature of $60^{\circ} \mathrm{C}$, in teflon batch reactors, sealed within steel cases.

Once the reaction time of the presetting experiments was finished, reactors were opened and aqueous and solid phases were separated by centrifugation at $4200 \mathrm{rpm}$ for 15 minutes in polypropylene tubes. $\mathrm{pH}$ was measured quickly in the soft aqueous suspension supernatants. $\mathrm{pH}$ values of 12.9 , $12.5,12.2$, and 11.8 were measured for the $1: 1,2: 1,3: 1$, and $4: 1$ montmorillonite $/ \mathrm{Ca}(\mathrm{OH})_{2}$ molar ratio aqueous samples, respectively. The remaining solid samples were immediately dried in a desiccator (in which $\mathrm{P}_{2} \mathrm{O}_{5}$ powder and separated $\mathrm{KOH}$ pellets were placed in order to capture water and $\mathrm{CO}_{2}$ ) with a vacuum extractor and then ground into powder and analyzed by X-ray diffraction (XRD) with a PHILLIPS XPERT PRO diffractometer with a X-CELERATOR detector ranging from 3 to $70^{\circ} 2 \theta$ using $\mathrm{CuK} \alpha_{1}$ radiation $(\lambda=$ $1.54056 \AA$ ) and $\mathrm{Ge}$ monochromator with divergence and reception slits of 2 and $0.6 \mathrm{~mm}$, respectively. The diffractometer operated at a voltage of $40 \mathrm{kV}$ and intensity of $40 \mathrm{~mA}$.

The 4 presetting experiments were examined by XRD and compared to a reference FEBEX bentonite (Figure 1). The sample with montmorillonite/portlandite ratio 1:1 showed reflections at 4.91 and $2.63 \AA$, indicative of excess of portlandite that did not react, and, therefore, this molar ratio was discarded for further experimental conditions. A sharp reflection at $10.63 \AA$ was observed for montmorillonite/portlandite molar ratios $1: 1,2: 1$, and $3: 1$ with decreasing intensity, but not for $4: 1$. This reflection is not present in the diffractograms of the reference FEBEX bentonite and suggests the precipitation of a crystalline phase that could be attributed to calcium aluminate hydrate, which could be formed in the first stages of reaction at low montmorillonite/ $\mathrm{Ca}(\mathrm{OH})_{2}$ ratio [27].

Consequently, the optimum montmorillonite/portlandite molar ratios for a longer-term reaction were established at $2: 1$ and $3: 1$ with the aim of enhancing the reactivity by the complete consumption of $\mathrm{Ca}(\mathrm{OH})_{2}$. Four experiments with FEBEX bentonite and four with the extracted $<2 \mu \mathrm{m}$ size fraction of this bentonite were set for a reaction time close to 2 months. For both types of samples and both montmorillonite and portlandite molar ratio, each experiment was performed at constant temperatures of $60^{\circ} \mathrm{C}$ and $120^{\circ} \mathrm{C}$. Solid to liquid mass ratio was maintained to be $1: 3$, but for the $<2 \mu \mathrm{m}$ size fraction experiments the mass of sample was decreased to $1.5 \mathrm{~g}$ instead of $5 \mathrm{~g}$. All other experimental conditions and methods were performed as for the presetting experiments, but the analysis of the solid phase also included a microscopy study with a scanning electron microscopy (SEM) PHILLIPS XL 30 with an energy-dispersive X-ray (EDX) analyzer.

\section{Results}

3.1. Scanning Electron Microscopy. The micromorphological study by SEM-EDX of samples at $60^{\circ} \mathrm{C}$, using bentonite with montmorillonite/portlandite molar ratio $2: 1$, revealed precipitation of short needle-like crystals of approximately $10 \mu \mathrm{m}$ in length, as well as spherical nodules, covering clay aggregates (Figure 2(a)). The needle-like crystals exhibit semiquantitative $\mathrm{Ca} / \mathrm{Si}$ and $\mathrm{Al} / \mathrm{Si}$ ratios of $1.27 \pm 0.24$ and $0.24 \pm 0.05$, respectively, according to $10 \mathrm{EDX}$ punctual analyses on the surface of these crystals in isolated positions. Only two EDX analyses were performed on the nodules, which had higher $\mathrm{Ca}$ and $\mathrm{Al}$ contents $(\mathrm{Ca} / \mathrm{Si}=1.61 \pm 0.04$ and $\mathrm{Al} / \mathrm{Si}=0.57 \pm 0.13$ ); however, all the nodules were found to be well mixed with the clay aggregates and so the composition of the clay could also be partially involved in the analyses.

The isometric crystals (nodules) were punctually detected at $60^{\circ} \mathrm{C}$ in experiments with montmorillonite at $3: 1$ montmorillonite/portlandite molar ratio. However, in the other experiments performed at $60^{\circ} \mathrm{C}, \mathrm{C}-(\mathrm{A})-\mathrm{S}-\mathrm{H}$ morphologies were not found, and only alteration of clay aggregates was observed (Figures 2(b), 2(c), and 2(d)).

Rounded clusters of bladed crystals were observed at $120^{\circ} \mathrm{C}$ in experiments using bentonite with montmorillonite/portlandite molar ratio 2:1 (Figure 2(e)). The EDX analyses performed on these bladed crystals revealed $\mathrm{Ca} / \mathrm{Si}$ and $\mathrm{Al} / \mathrm{Si}$ ratios of $0.75 \pm 0.03$ and $0.26 \pm 0.02$, respectively. Increasing the montmorillonite/portlandite ratio to $3: 1, \mathrm{C}$ (A)-S-H phases were found with a more fibrous aspect, mixed with clay aggregates (Figure 2(f)). Seven EDX analyses were performed on the surface of these fibers. The $\mathrm{Ca} / \mathrm{Si}$ and $\mathrm{Al} / \mathrm{Si}$ ratios obtained were $0.65 \pm 0.05$ and $0.26 \pm 0.04$, respectively.

At $120^{\circ} \mathrm{C}$ using montmorillonite and montmorillonite/ portlandite molar ratio $2: 1$, rounded clusters of bladed crystals were observed covering montmorillonite aggregates (Figure 2(g)). Based on six EDX analyses performed on this type of mineral phase habit, the $\mathrm{Ca} / \mathrm{Si}$ and $\mathrm{Al} / \mathrm{Si}$ ratios were $0.45 \pm 0.03$ and $0.26 \pm 0.04$, respectively. Increasing the montmorillonite/portlandite ratio to $3: 1$, similar fibrous morphologies as those observed in experiments with bentonite were found (Figure 2(h)). However, in this case, the $\mathrm{Ca} / \mathrm{Si}$ and $\mathrm{Al} / \mathrm{Si}$ determined ratios were $0.60 \pm 0.06$ and $0.29 \pm$ 0.04 , respectively, taken from $11 \mathrm{EDX}$ analyses. 


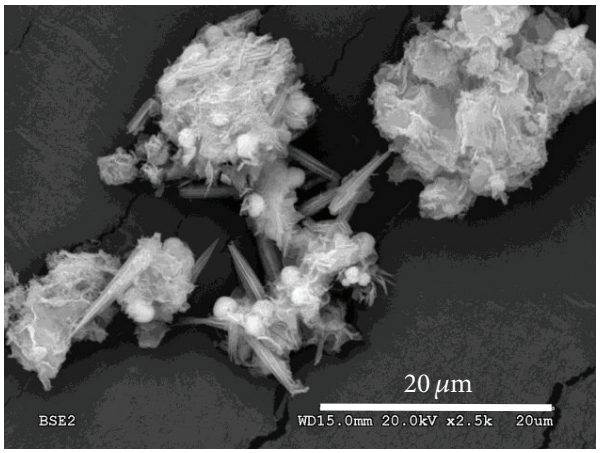

(a)

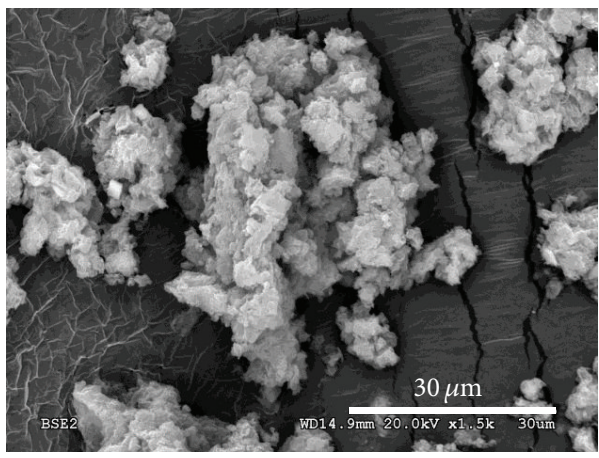

(c)

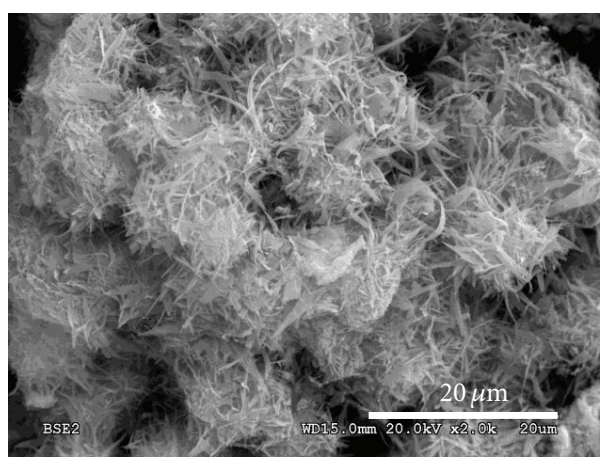

(e)

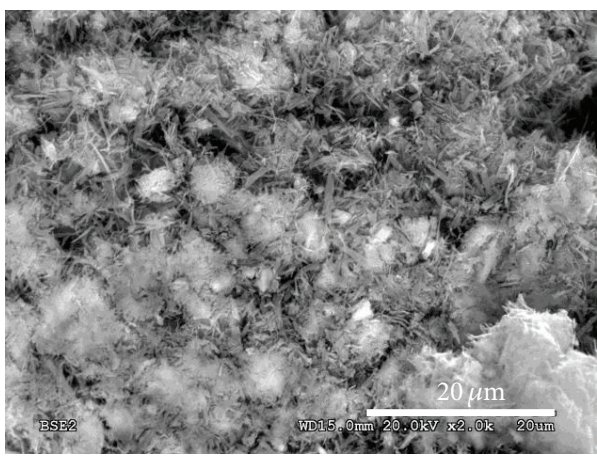

(g)

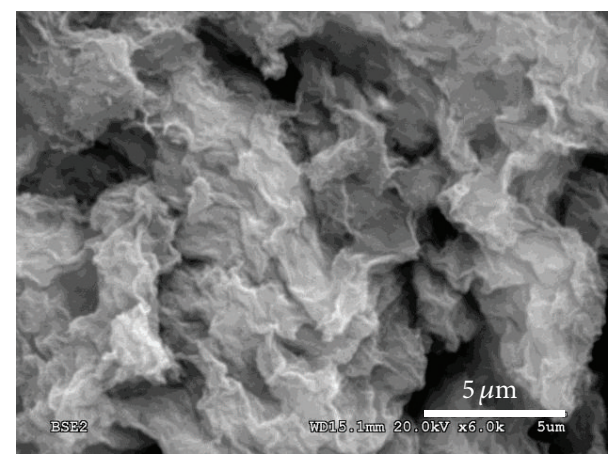

(b)

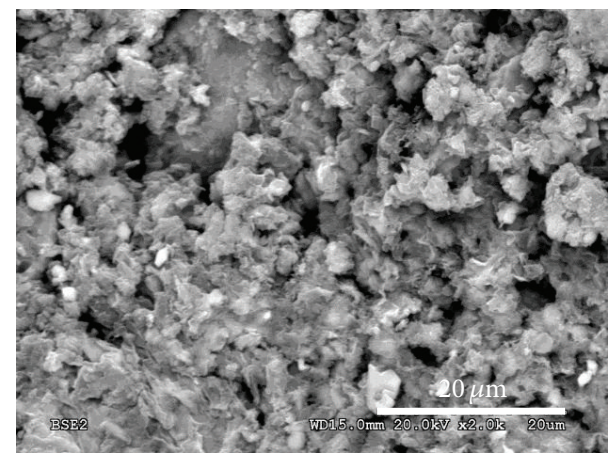

(d)

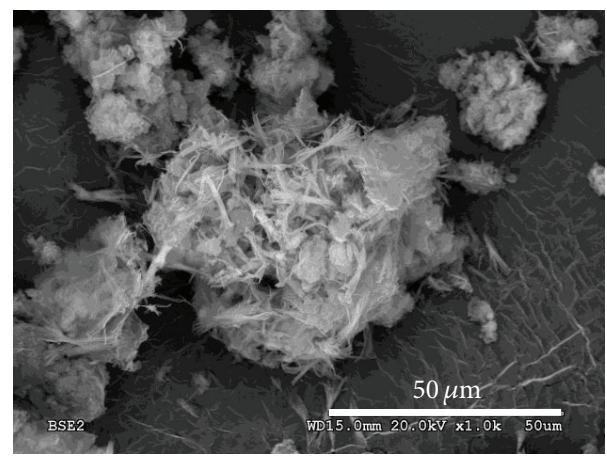

(f)

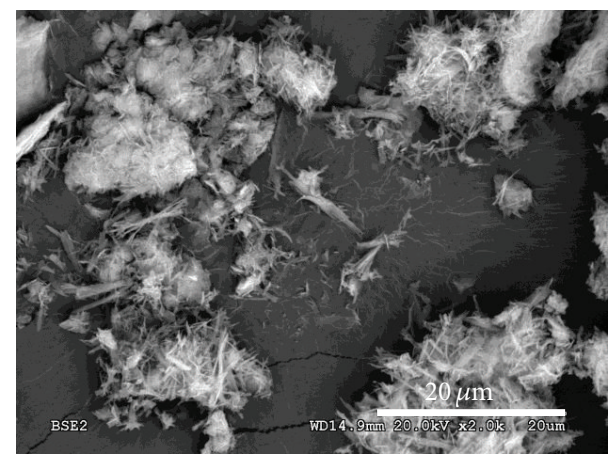

(h)

FIGURE 2: Morphologies of reacted samples observed by SEM in experiments with the following conditions: starting material, temperature, and montmorillonite/portlandite molar ratio (a) bentonite $60^{\circ} \mathrm{C}, 2: 1$; (b) bentonite $60^{\circ} \mathrm{C}, 3: 1$; (c) montmorillonite $60^{\circ} \mathrm{C}$, $2: 1$; $(\mathrm{d})$ montmorillonite $60^{\circ} \mathrm{C}, 3: 1$; (e) bentonite $120^{\circ} \mathrm{C}, 2: 1$; (f) bentonite $120^{\circ} \mathrm{C}, 3: 1$; (g) montmorillonite $120^{\circ} \mathrm{C}, 2: 1$; and (h) montmorillonite $120^{\circ} \mathrm{C}$, $3: 1$. 


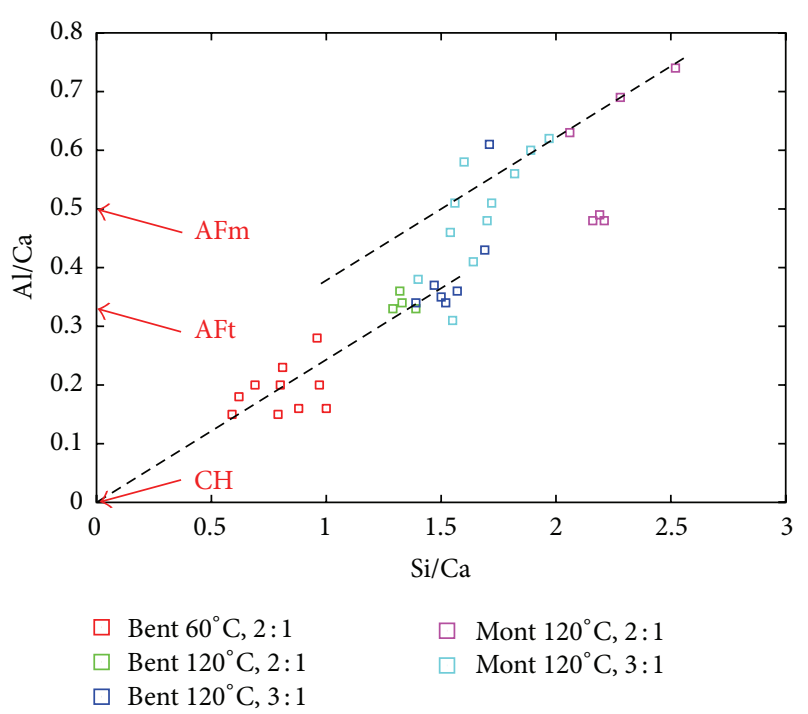

Figure 3: $\mathrm{Al} / \mathrm{Ca}$ against $\mathrm{Si} / \mathrm{Ca}$ atom ratio plots for the EDX analyses of C-(A)-S-H crystals in experiments with bentonite (Bent) and montmorillonite (Mont) at 60 and $120^{\circ} \mathrm{C}$ and montmorillonite/portlandite molar ratios $2: 1$ and $3: 1$. CH: portlandite; Aft: ettringite; AFm: hydrated calcium aluminates.

Considering the chemical compositions obtained by the SEM-EDX analyses on the C-(A)-S-H structures, a clear increase in the $\mathrm{Al} / \mathrm{Ca}$ and $\mathrm{Si} / \mathrm{Ca}$ ratios can be observed accompanied by the increase of temperature and removal of accessory minerals in bentonite (Figure 3). These trends are typical of a cement paste undergoing hydration [28, 29] and can normally be observed for the formation of C-S$\mathrm{H}$ phases and of AFm (hydrated calcium aluminates [30]) and AFt (ettringite) phases that obviously do not participate in the present reaction. The plotted compositions indicate the formation of C-(A)-S-H, exclusively from portlandite (at the origin, with cement chemistry notation $\mathrm{CH}$ in Figure 3), in its reaction with bentonite or montmorillonite. Assuming the ideal stoichiometric formula of montmorillonite shown previously $\left(\mathrm{Ca}_{0.165} \mathrm{Mg}_{0.33} \mathrm{Al}_{1.67} \mathrm{Si}_{4} \mathrm{O}_{10}(\mathrm{OH})_{2}\right)$, the $\mathrm{Si} / \mathrm{Ca}$ and $\mathrm{Al} / \mathrm{Ca}$ coordinates for montmorillonite would be at $(24.2,10.1)$ if plotted in Figure 3 , but the $X$ coordinate will increase in higher proportion than $Y$ if bentonite is considered due to the addition of accessory minerals that contain more Si than $\mathrm{Al}$. In experiments with bentonite, a compositional effect with the increase of temperature (low Si/Ca ratios) can be observed, as well as another compositional effect with the removal of accessory minerals in bentonite. By comparison, the experiments with montmorillonite exhibit a trend (dashed lines in Figure 3) of slightly elevated $\mathrm{Al} / \mathrm{Ca}$ ratios for similar $\mathrm{Si} / \mathrm{Ca}$ ratios.

3.2. X-Ray Diffraction. There is a marked difference between the results obtained at 60 and $120^{\circ} \mathrm{C}$ regardless of the use of bentonite or its size fraction $<2 \mu \mathrm{m}$. At $60^{\circ} \mathrm{C}$, characteristic reflections of monoclinic tobermorite (also referred to as clinotobermorite [31]: $\mathrm{Ca}_{5} \mathrm{Si}_{6} \mathrm{O}_{17} \cdot 5 \mathrm{H}_{2} \mathrm{O}$ ) were identified at 3.06 and $3.04 \AA$, which correspond to a mineral phase with

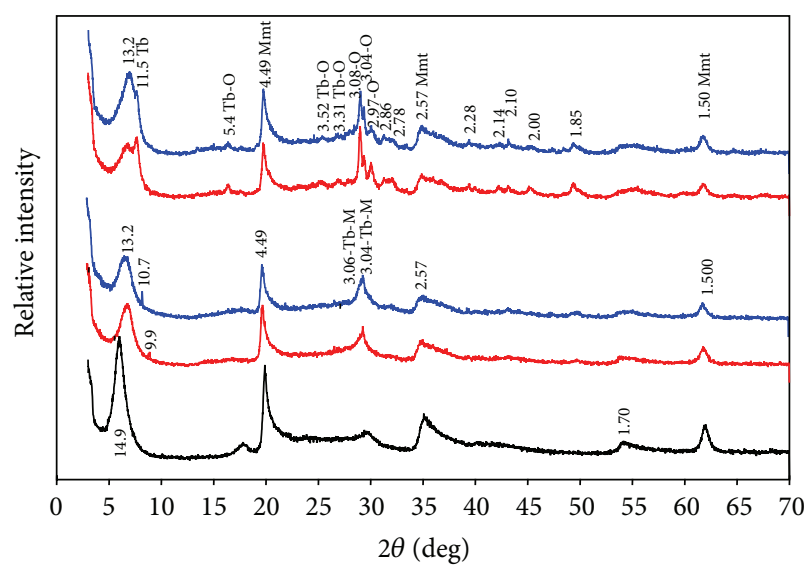

FIGURE 4: XRD for experiments using montmorillonite at $120^{\circ} \mathrm{C}$ (top) and $60^{\circ} \mathrm{C}$ (middle) compared to a reference FEBEX bentonite (bottom, in black color). Experiments with 2:1 montmorillonite/portlandite molar ratio are shown in blue and $3: 1$ in red color. Mnt: montmorillonite; Tb-O: orthorhombic tobermorite; $\mathrm{Tb}$ M: monoclinic tobermorite.

almost identical chemical composition to that of orthorhombic $11 \AA$-tobermorite $\left(\mathrm{Ca}_{4+x} \mathrm{Si}_{6} \mathrm{O}_{15+2 x}(\mathrm{OH})_{2-2 x} \cdot 5 \mathrm{H}_{2} \mathrm{O}\right.$ [32] $)$, but with a more disordered structure. The most intense reflection of unsubstituted tobermorite, which should have been observed at 11.2-11.25 $\AA$, was not present. Instead a $10.7 \AA$ sharp reflection (calcium aluminate) was observed for the $2: 1$ montmorillonite/portlandite molar ratio experiment, as well as a reflection at $9.9 \AA$ for the $3: 1$ molar ratio.

At $120^{\circ} \mathrm{C}$, orthorhombic $11 \AA$-tobermorite was identified by reflections at 11.5-11.6 $\AA$, 3.08 $\AA$ (the two are more intensive) and reflections at 5.4, 3.52, 3.31, 3.04, and $2.97 \AA$ ([28] and references therein). The XRD results at 60 and $120^{\circ} \mathrm{C}$ for the experiments with montmorillonite, compared to a reference unreacted FEBEX bentonite, are shown in Figure 4.

Changes in the XRD reflection corresponding to the basal spacing of montmorillonite were observed in all experiments. A broad reflection with highest intensity at $\approx 15 \AA$ was observed at $120^{\circ} \mathrm{C}$ in the experiment with bentonite at montmorillonite/portlandite molar ratio $3: 1$ that could be attributed to a Ca-montmorillonite. However, this reflection is overlain by other maxima at 13.2, 12.6, and 11.6 $\AA$. The 12.6 reflection could be attributed to $\mathrm{Na}$ or $\mathrm{K}$ montmorillonite, although sodium and potassium were not significantly present in the reaction, and the reflection at $11.6 \AA$ could be attributed to a disordered-tobermorite-like phase. Nevertheless, the reflection at $13.2 \AA$ does not correspond to Ca-montmorillonite or tobermorite. At $120^{\circ} \mathrm{C}$ and montmorillonite/portlandite molar ratio $2: 1$ the reflection corresponding to the basal spacing of montmorillonite has disappeared and only a reflection with intensity at $11.6 \AA$ is present. However, it should be noted that $(\mathrm{hk} 0)$ reflections of montmorillonite were still present at $d$-spacings of 4.45 and $1.50 \AA$. At $60^{\circ} \mathrm{C}$, the highest intensity of the characteristic reflection for the basal spacing of montmorillonite has decreased from $15 \AA$ and it is characterized, for both 


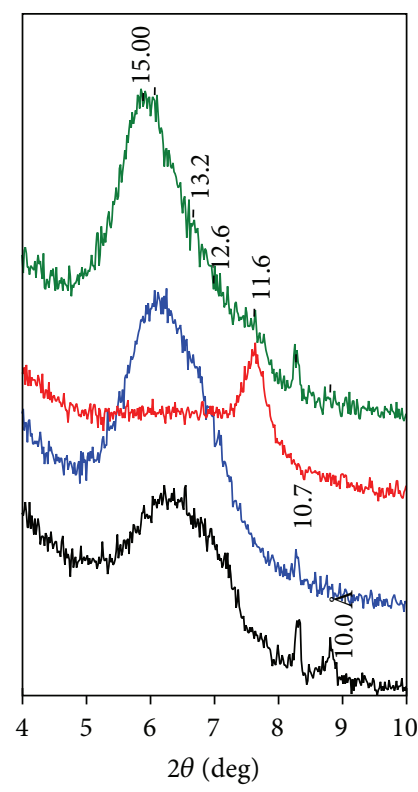

(a)

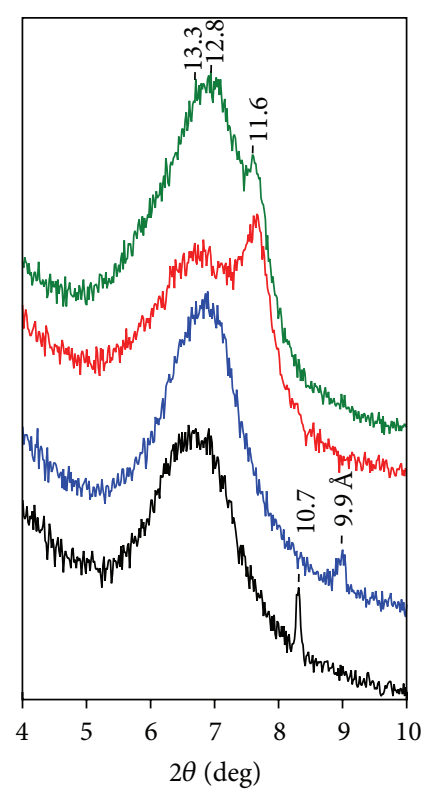

(b)

FIGURE 5: Details of XRD at low angles for (a) experiments using bentonite and (b) experiments using montmorillonite. Notation of color is green for experiments with montmorillonite/portlandite molar ratio $3: 1$ at $120^{\circ} \mathrm{C}$; red for $2: 1$ at $120^{\circ} \mathrm{C}$; blue for $3: 1$ at $60^{\circ} \mathrm{C}$; and black for $2: 1$ at $60^{\circ} \mathrm{C}$.

molar ratios $(2: 1$ and $3: 1)$, by a maximum at $13.2-13.3 \AA$ (Figure 5(a)).

A broad reflection with highest intensity at 13.3-12.8 was observed at 60 and $120^{\circ} \mathrm{C}$ in experiments with montmorillonite. In addition, at $120^{\circ} \mathrm{C}$, a second reflection at $11.6 \AA$ is observed while at $60^{\circ} \mathrm{C}$ reflections at 10.7 and $9.9 \AA$ are detected in experiments with montmorillonite/portlandite molar ratio $2: 1$ and $3: 1$, respectively (Figure 5(b)).

\section{Discussion}

Using similar experimental conditions as those developed in the present study, Kaufhold and Dohrmann [33] evaluated the stability of 38 different bentonites immersed in saturated and oversaturated $\mathrm{Ca}(\mathrm{OH})_{2}$ solutions in batch reactors at $60^{\circ} \mathrm{C}$ for 5 months and at $90^{\circ} \mathrm{C}$ for 3 months, with the aim of identifying differences in the reactivity of the materials. Except for $\mathrm{pH}$ buffering to values lower than 10 and cation exchange in smectites $\left(\mathrm{Ca}^{2+}\right.$ partially replacing $\mathrm{Na}^{+}$ and $\mathrm{Mg}^{2+}$ ), no significant changes were observed in their study at $60^{\circ} \mathrm{C}$. At $90^{\circ} \mathrm{C}$, significant amounts of carbonates precipitated but were attributed to reaction of $\mathrm{Ca}(\mathrm{OH})_{2}$ with atmospheric $\mathrm{CO}_{2}$. Not any other reaction product was found by XRD or infrared (IR) spectroscopic analyses; however, the hypothesis of formation of reaction products below detection limits or precipitation of amorphous products was left open. Differences in the solubility of the 38 bentonites under these experimental conditions could not be found, proving the complexity to derive conclusive results from this type of experiments and evidencing the value of estimation techniques to calculate thermodynamic properties for geochemical modelling. The methodology used in our study, which prioritized the impairment of carbonates precipitation and favored the use of portlandite reaction added as solid instead of using a saturated solution, is demonstrated to be effective to identify the precipitation of C-(A)-S-H phases.

Mantovani et al. [34] evaluated the stability of several phyllosilicates in $\mathrm{Ca}(\mathrm{OH})_{2}$ solution, one of them being a Carich montmorillonite. Their experiments were performed in batch reactors at $300^{\circ} \mathrm{C}$ for a duration of 5 days. The study by XRD of the treated montmorillonite showed formation of new crystalline phases, with the main ones being a lowsymmetry triclinic polymorph of anorthite $\left(\mathrm{CaAl}_{2} \mathrm{Si}_{2} \mathrm{O}_{8}\right)$ and xonotlite $\left(\mathrm{Ca}_{6} \mathrm{Si}_{6} \mathrm{O}_{17}(\mathrm{OH})_{2}\right)$ and a high-temperature calcium silicate hydrate. In addition, $11 \AA$-tobermorite was also identified as a minor phase. The high temperature applied increases the reactivity and produces crystalline phases. In this sense, precipitation of orthorhombic $11 \AA$ tobermorite is detected as a reaction product in the system montmorillonite/portlandite under hydrothermal conditions within a wide range of temperatures, from $120^{\circ} \mathrm{C}$ (our study) to $300^{\circ} \mathrm{C}[34]$.

The tobermorite-like structures identified by XRD in the present study might contain a high degree of $\mathrm{Al}$ substitution for $\mathrm{Si}$, very limited substitution of $\mathrm{Mg}$ for $\mathrm{Ca}$, and negligible substitution of $\mathrm{Na}$ for $\mathrm{Ca}$, as detected by the EDX analyses. This is in agreement with Pardal et al. [35], who prepared C-A$\mathrm{S}-\mathrm{H}$ from C-S-H and a hydrogarnet $\left(\mathrm{C}_{3} \mathrm{AH}_{6}\right)$ saturated solution and observed that the produced C-A-S-H maintained the tobermorite structure. The maximum $\mathrm{Al} / \mathrm{Si}$ ratio they found in C-A-S-H was 0.19, which is in agreement with other studies, either experimental (e.g., [36]) or recently found in a Roman concrete immersed in seawater [18], in which a wide interlayer spacing, $11.49 \AA$, for $\mathrm{Al}$ substituted tobermorite is 
reported in close agreement with our XRD results. However, the $\mathrm{Al} / \mathrm{Si}$ ratio in all those studies was lower than the $\mathrm{Al} / \mathrm{Si}$ found in the present study, which is within the range of $0.24-$ 0.29. The excess in Al determined in the present study in comparison with previous works could be associated with the presence of aluminates at the nano-microscale, which could have been identified by the isometric crystals with high $\mathrm{Ca}$ content found at $60^{\circ} \mathrm{C}$ by SEM, affecting the EDX analyses and contributing to the $10.7 \AA$ reflection observed in the XRD pattern.

The XRD results in this study showed a reflection at 13.2-13.3 $\AA$ in all experiments that has not been attributed to a single mineral phase. This reflection could be the effect of intercalation or association at the structural scale of montmorillonite and tobermorite. Additional analyses are required to either confirm or reject the latter hypothesis.

The reactions of montmorillonite and portlandite seem to produce higher $\mathrm{Si} / \mathrm{Ca}$ phases, but the analyses incorporate more $\mathrm{Al}$ than the bentonite reactions (see upper regression trend in Figure 3). The reason could be the result of selective silica dissolution in bentonite (quartz and cristobalite present) and precipitation of C-A-S-H in a porous environment maintained by the presence of accessory minerals whose precipitation takes place outside of or far from the dissolution surface. On the contrary, by the removal of accessory minerals in bentonite, mineral dissolution is less selective from montmorillonite and facilitates the incorporation of $\mathrm{Al}$ and $\mathrm{Si}$ (Al/Si: $0.5-0.4$ in montmorillonite) in the C-A$\mathrm{S}-\mathrm{H}$ structure, precipitated at the montmorillonite- $\mathrm{Ca}(\mathrm{OH})_{2}$ reaction surface.

The minerals and compositions found in this study should help to limit the choice of secondary minerals and narrow down the range of possible solid/solution chemical compositions used in future geochemical modeling works related to the study of concrete/bentonite interactions in the context of radioactive waste disposal.

\section{Conclusions}

Precipitation of C-(A)-S-H phases has been successfully produced by the hydrothermal reactions bentonite/portlandite and montmorillonite/portlandite in batch experiments. Certain substitution of $\mathrm{Al}$ for $\mathrm{Si}$ (in the range $0.24-0.29$ ), very limited substitution of $\mathrm{Mg}$ for $\mathrm{Ca}$, and negligible substitution of $\mathrm{Na}$ for $\mathrm{Ca}$ have been found. Therefore, based on the compositional results, the target product should be identified as $\mathrm{C}-(\mathrm{A})-\mathrm{S}-\mathrm{H}$, although some $\mathrm{C}-\mathrm{A}-\mathrm{H}$ might also be present. The designed methodology and working conditions used (free of atmospheric $\mathrm{CO}_{2}$ ) were validated by the lack of precipitation of secondary carbonates. The morphology and composition of the formed C-(A)-S-H phases depends on the reaction conditions. Orthorhombic $11 \AA$-tobermorite was distinguished by XRD in experiments performed at $120^{\circ} \mathrm{C}$ and a more disordered monoclinic tobermorite phase at $60^{\circ} \mathrm{C}$. An XRD reflection at 13.2-13.3 $\AA$ was observed in all experiments and could not be attributed to montmorillonite nor to tobermorite but could suggest either intercalation at the structural scale of both laminar minerals or association. The latter should be further confirmed by additional analytical techniques.

\section{Conflict of Interests}

The authors declare that there is no conflict of interests regarding the publication of this paper.

\section{Acknowledgment}

The contribution of two anonymous reviewers to the improvement of this paper has been highly appreciated.

\section{References}

[1] R. Fernández, J. Cuevas, L. Sánchez, R. V. de la Villa, and S. Leguey, "Reactivity of the cement-bentonite interface with alkaline solutions using transport cells," Applied Geochemistry, vol. 21, no. 6, pp. 977-992, 2006.

[2] F. Dolder, U. Mäder, A. Jenni, and N. Schwendener, "Experimental characterization of cement-bentonite interaction using core infiltration techniques and 4D computed tomography," Physics and Chemistry of the Earth Parts $A / B / C$, vol. 70-71, pp. 104-113, 2014.

[3] S. Ramírez, J. Cuevas, R. Vigil, and S. Leguey, "Hydrothermal alteration of "La Serrata" bentonite (Almeria, Spain) by alkaline solutions," Applied Clay Science, vol. 21, no. 5-6, pp. 257-269, 2002.

[4] L. Sánchez, J. Cuevas, S. Ramírez et al., "Reaction kinetics of FEBEX bentonite in hyperalkaline conditions resembling the cement-bentonite interface," Applied Clay Science, vol. 33, no. 2, pp. 125-141, 2006.

[5] D. Savage, D. Noy, and M. Mihara, "Modelling the interaction of bentonite with hyperalkaline fluids," Applied Geochemistry, vol. 17, no. 3, pp. 207-223, 2002.

[6] C. Watson, K. Hane, D. Savage, S. Benbow, J. Cuevas, and R. Fernandez, "Reaction and diffusion of cementitious water in bentonite: results of "blind" modelling," Applied Clay Science, vol. 45, no. 1-2, pp. 54-69, 2009.

[7] E. C. Gaucher, P. Blanc, J.-M. Matray, and N. Michau, "Modeling diffusion of an alkaline plume in a clay barrier," Applied Geochemistry, vol. 19, no. 10, pp. 1505-1515, 2004.

[8] A. Bauer and G. Berger, "Kaolinite and smectite dissolution rate in high molar $\mathrm{KOH}$ solutions at $35 \circ$ and $80 \circ \mathrm{C}$," Applied Geochemistry, vol. 13, no. 7, pp. 905-916, 1998.

[9] F. Rassineux, L. Griffault, A. Meunier et al., "Expandabilitylayer stacking relationship during experimental alteration of a Wyoming bentonite in $\mathrm{pH} 13.5$ solutions at 35 and 60॰C," Clay Minerals, vol. 36, no. 2, pp. 197-210, 2001.

[10] J. Cuevas, R. V. de la Villa, S. Ramírez, L. Sánchez, R. Fernández, and S. Leguey, "The alkaline reaction of FEBEX bentonite: a contribution to the study of the performance of bentonite/concrete engineered barrier systems," Journal of Iberian Geology, vol. 32, no. 2, pp. 151-174, 2006.

[11] S. Ramirez, D. Righi, and S. Petit, "Alteration of smectites induced by hydrolytic exchange," Clay Minerals, vol. 40, no. 1, pp. 15-24, 2005.

[12] D. Read, F. P. Glasser, C. Ayora, M. T. Guardiola, and A. Sneyers, "Mineralogical and microstructural changes accompanying the interaction of Boom Clay with ordinary Portland cement," Advances in Cement Research, vol. 13, no. 4, pp. 175-183, 2001. 
[13] J. A. Chermak, "Low temperature experimental investigation of the effect of high $\mathrm{pH} \mathrm{KOH}$ solutions on the Opalinus Shale, Switzerland," Clays and Clay Mineral, vol. 41, no. 3, pp. 365-372, 1993.

[14] D. Savage, K. Bateman, P. Hill et al., "Rate and mechanism of the reaction of silicates with cement pore fluids," Applied Clay Science, vol. 7, no. 1-3, pp. 33-45, 1992.

[15] D. Savage, C. Walker, R. Arthur, C. Rochelle, C. Oda, and H. Takase, "Alteration of bentonite by hyperalkaline fluids: a review of the role of secondary minerals," Physics and Chemistry of the Earth Parts A/B/C, vol. 32, no. 1-7, pp. 287-297, 2007.

[16] H. F. W. Taylor, "Nanostructure of C-S-H: current status," Advanced Cement Based Materials, vol. 1, no. 1, pp. 38-46, 1993.

[17] D. A. Kulik, "Improving the structural consistency of C-S-H solid solution thermodynamic models," Cement and Concrete Research, vol. 41, no. 5, pp. 477-495, 2011.

[18] M. D. Jackson, S. R. Chae, S. R. Mulcahy et al., "Unlocking the secrets of Al-tobermorite in Roman seawater concrete," American Mineralogist, vol. 98, no. 10, pp. 1669-1687, 2012.

[19] S. Komarneni, E. Breval, M. Miyake, and R. Roy, "Cationexchange properties of $(\mathrm{Al}+\mathrm{Na})$-substituted synthetic tobermorites," Clays and Clay Minerals, vol. 35, no. 5, pp. 385-390, 1987.

[20] D. R. M. Brew and F. P. Glasser, "Synthesis and characterisation of magnesium silicate hydrate gels," Cement and Concrete Research, vol. 35, no. 1, pp. 85-98, 2005.

[21] E. S. Hodgkinson and C. R. Hughes, "The mineralogy and geochemistry of cement/rock reactions: high-resolution studies of experimental and analogue materials," Geological Society, vol. 157, no. 1, pp. 195-211, 1999.

[22] E. C. Gaucher and P. Blanc, "Cement/clay interactions-a review: experiments, natural analogues, and modeling," Waste Management, vol. 26, no. 7, pp. 776-788, 2006.

[23] D. Savage, J. M. Soler, K. Yamaguchi et al., "A comparative study of the modelling of cement hydration and cement-rock laboratory experiments," Applied Geochemistry, vol. 26, no. 7, pp. 1138-1152, 2011.

[24] E. Caballero, C. J. de Cisneros, F. J. Huertas, A. Pozzuoli, and J. Linares, "Bentonites from Cabo de Gata, Almería Spain: a mineralogical and geochemical overview," Clay Minerals, vol. 40, no. 4, pp. 463-480, 2005.

[25] A. M. Fernández, B. Baeyens, M. Bradbury, and P. Rivas, "Analysis of the porewater chemical composition of a Spanish compacted bentonite used in an engineered barrier," Physics and Chemistry of the Earth, vol. 29, no. 1, pp. 105-118, 2004.

[26] D. Savage, C. Walker, and S. Benbow, "An analysis of potential changes to barrier components due to interaction with a concrete liner in a repository for SF/HLW in Opalinus Clay," NAB 10-17, Nagra, Wettingen, Switzerland, 2010.

[27] G. R. Glenn, "X-ray studies of lime-bentonite reaction products," Journal of the American Ceramic Society, vol. 50, no. 6, pp. 312-316, 1967.

[28] I. G. Richardson, "The calcium silicate hydrates," Cement and Concrete Research, vol. 38, no. 2, pp. 137-158, 2008.

[29] I. G. Richardson, "Nature of C-S-H in hardened cements," Cement and Concrete Research, vol. 29, no. 8, pp. 1131-1147, 1999.

[30] T. Matschei, B. Lothenbach, and F. P. Glasser, "The AFm phase in Portland cement," Cement and Concrete Research, vol. 37, no. 2, pp. 118-130, 2007.

[31] C. Henmi and I. Kusachi, "Clinotobermorite, $\mathrm{Ca}_{5} \mathrm{Si}_{6}(\mathrm{O}$, $\mathrm{OH})_{18} \cdot 5 \mathrm{H}_{2} \mathrm{O}$, a new mineral from Fuka, Okayama Prefecture, Japan," Mineralogical Magazine, vol. 56, pp. 353-358, 1992.
[32] S. Merlino, E. Bonaccorsi, and T. Armbruster, "Tobermorites: their real structure and order-disorder (OD) character," The American Mineralogist, vol. 84, no. 10, pp. 1613-1621, 1999.

[33] S. Kaufhold and R. Dohrmann, "Stability of bentonites in salt solutions III-calcium hydroxide," Applied Clay Science, vol. 51, no. 3, pp. 300-307, 2011.

[34] M. Mantovani, A. Escudero, M. D. Alba, and A. I. Becerro, "Stability of phyllosilicates in $\mathrm{Ca}(\mathrm{OH}) 2$ solution: influence of layer nature, octahedral occupation, presence of tetrahedral $\mathrm{Al}$ and degree of crystallinity," Applied Geochemistry, vol. 24, no. 7, pp. 1251-1260, 2009.

[35] X. Pardal, I. Pochard, and A. Nonat, "Experimental study of Si$\mathrm{Al}$ substitution in calcium-silicate-hydrate (C-S-H) prepared under equilibrium conditions," Cement and Concrete Research, vol. 39, no. 8, pp. 637-643, 2009.

[36] G. K. Sun, J. F. Young, and R. J. Kirkpatrick, "The role of Al in C-S-H: NMR, XRD, and compositional results for precipitated samples," Cement and Concrete Research, vol. 36, no. 1, pp. 1829, 2006. 

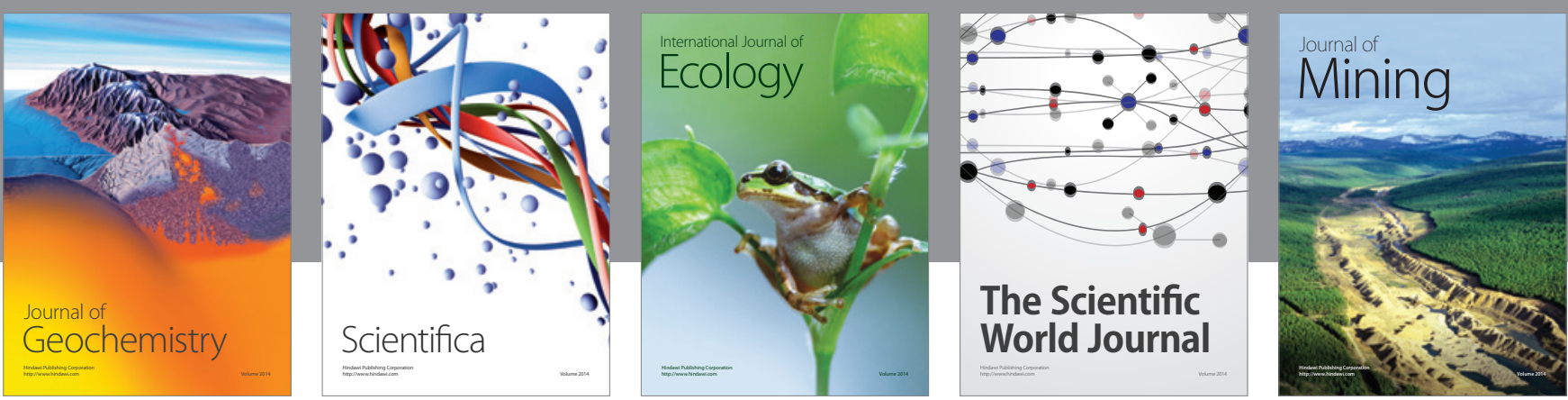

The Scientific World Journal
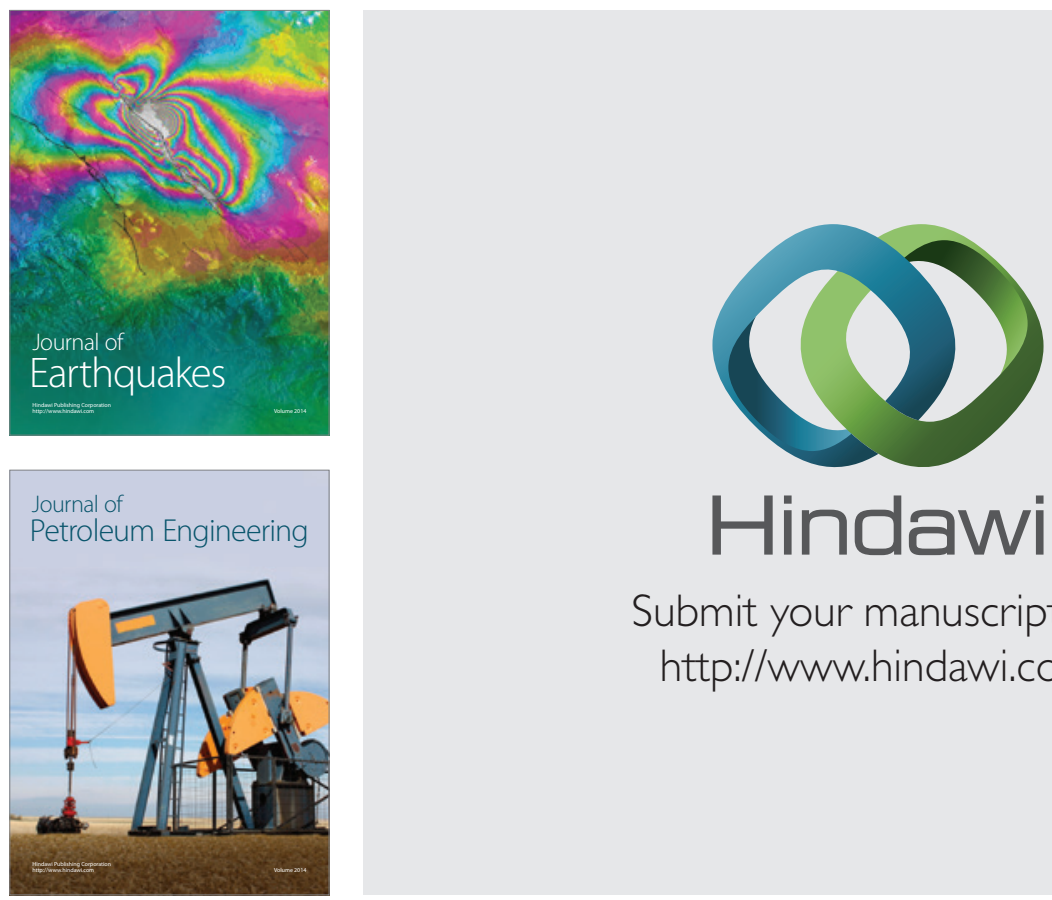

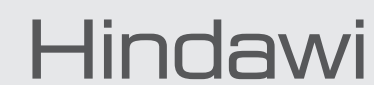

Submit your manuscripts at

http://www.hindawi.com
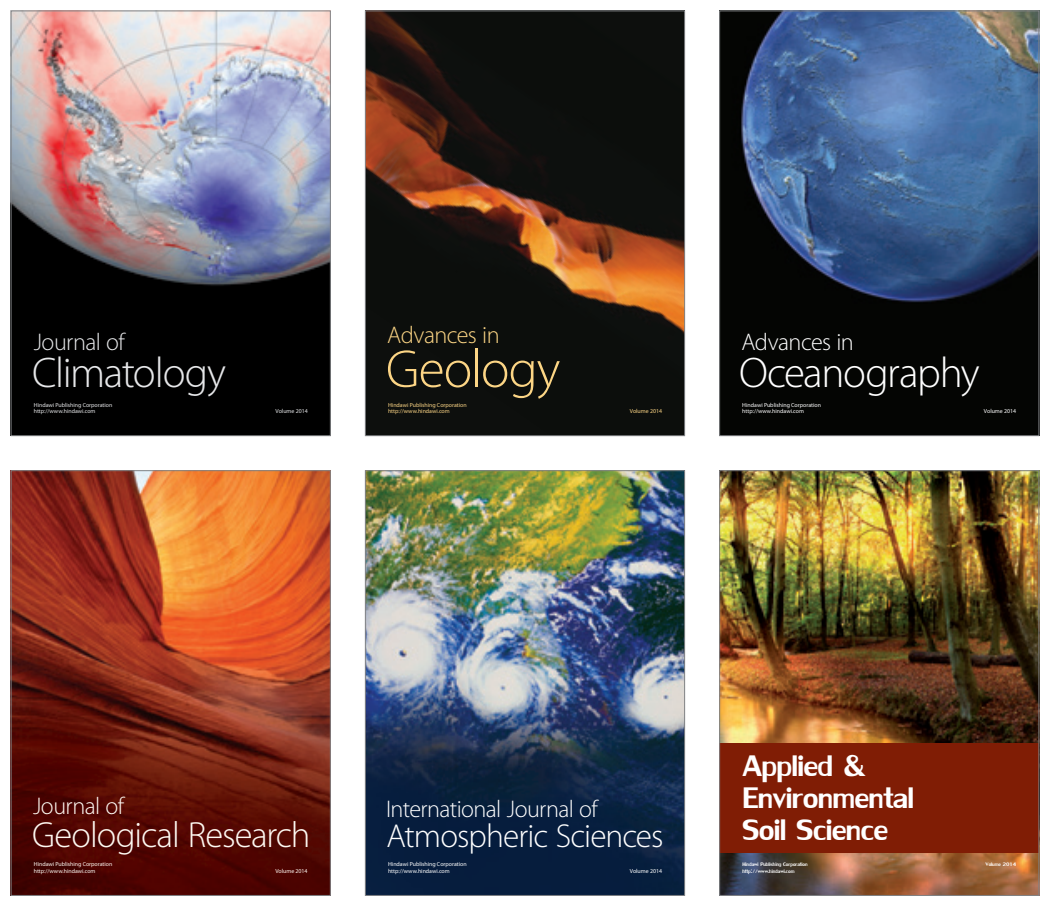
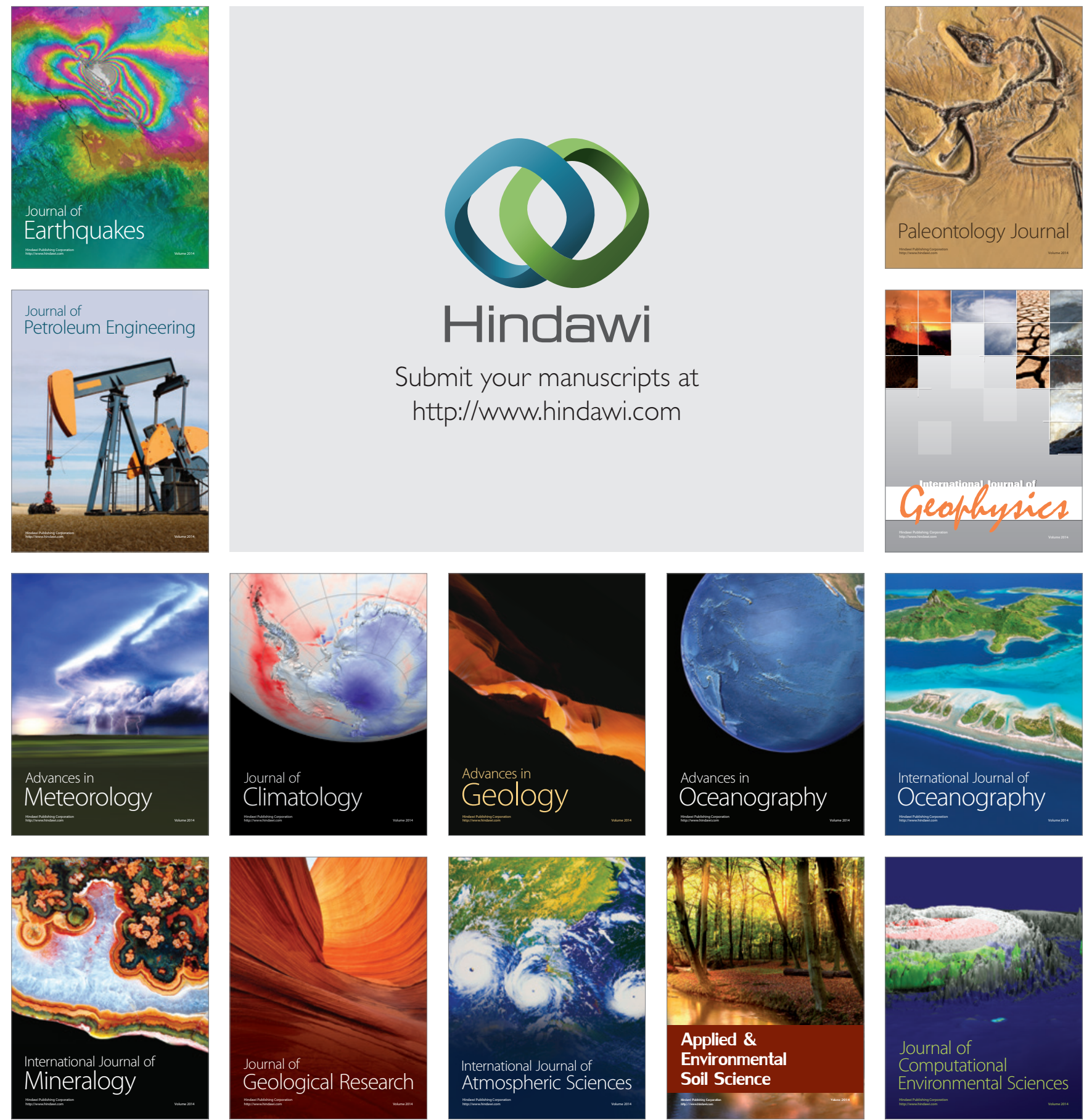